\title{
Spirometric lung function tests in normal non-smoking Ethiopian men and women
}

\author{
YOSEPH A MENGESHA, YALEMTSEHAY MEKONNEN
}

From the Faculty of Medicine and Department of Biology, Addis Ababa University, Addis Ababa, Ethiopia

ABSTRACT Forced vital capacity (FVC), $\mathrm{FEV}_{1}, \mathrm{FEV}_{1} / \mathrm{FVC}$ ratio $\left(\mathrm{FEV}_{1} \%\right)$, forced expiratory flow $\left(F_{2 F} F_{20-1200}\right)$, and peak expiratory flow rate (PEFR) were measured in 143 male and 117 female healthy Ethiopians. Multiple linear regression analysis was used to correlate these indices with anthropometric variables. The results show that FVC, FEV , and PEFR give significant regressions with age and height in both sexes. These indices have significant regression coefficients with percentage body fat, weight, and fat free mass (FFM) expressed independently of height in the men; only PEFR is significantly regressed on weight and FFM in the women. FVC and $\mathrm{FEV}_{1}$ in Ethiopians are found to be lower than in caucasians and higher than in other Africans, Chinese, and Indians. Prediction equations are provided for future use for obtaining reference values for lung function indices in similar subjects.

Lung function in relation to age and height has been studied extensively in caucasians, ${ }^{1-4}$ in whom these indices show correlations with forced vital capacity (FVC), $\mathrm{FEV}_{1}, \mathrm{FEV}_{1} / \mathrm{FVC}$ ratio $\left(\mathrm{FEV}_{1} \%\right)$, and forced expiratory flow $\left(\mathrm{FEF}_{200-1200}\right)$. Ethnic differences in lung function have also been reported by many authors. ${ }^{5-10} \mathrm{FVC}$ and $\mathrm{FEV}_{1}$ have been shown to be lower in African blacks than in whites, while Indians and Chinese have intermediate FVC and $\mathrm{FEV}_{1}$ values. African workers ${ }^{1112}$ have also measured FVC, FEV 1 and peak expiratory flow rate (PEFR) in healthy African blacks.

The present study of healthy non-smoking Ethiopians aimed, firstly, to establish the relationships of lung function indices $\left(\mathrm{FVC}, \mathrm{FEV}_{1}, \mathrm{FEV}_{1} \%, \mathrm{FEF}\right.$, and PEFR) with (a) age and height; (b) age, height, and body weight divided by the square of height; and $(c)$ age, height, percentage fat and fat free mass (FFM) divided by the square of height and, secondly, to compare the lung function indices found in Ethiopians with indices obtained from other racial groups.

Address for reprint requests: Dr Yoseph A Mengesha, Faculty of Medicine, Addis Ababa University, PO Box 1176, Addis Ababa, Ethiopia.

Accepted 28 October 1984

\section{Subjects and methods}

Ventilatory lung function tests (FVC, FEV

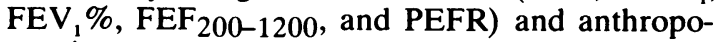
metric measurements were performed on 117 women and 143 men in apparent good health. The subjects (aged 18-47 years) were volunteers comprising students, civil servants, housewives, and essentially sedentary subjects from three localities (altitude range 1585-2757 m) in Ethiopia. After routine clinical examination normal subjects were selected by means of a standard questionnaire of respiratory symptoms, based on the recommendation of the British Medical Research Council. ${ }^{13}$ None of the subjects was a smoker. The number of the subjects by age groups is shown in table 1 .

Height and weight were measured to the nearest centimetre and kilogram. Fat free mass and percentage body fat were obtained from equations given by Durnin and Rahaman ${ }^{14}$ from measurements of body weight and skinfold thickness. The skinfold thickness was measured with the Harpenden skinfold

Table 1 Subjects subdivided by age groups

\begin{tabular}{lllll}
\hline Sex & \multicolumn{2}{l}{ Age $(y)$} & & Total \\
\cline { 2 - 4 } & $18-27$ & $28-37$ & $38-47$ & \\
\hline Male & 78 & 51 & 14 & 143 \\
Female & 60 & 35 & 22 & 117 \\
\hline
\end{tabular}


Table 2 Means and standard deviations (SD) of the anthropometric measurements

\begin{tabular}{|c|c|c|c|c|c|c|c|c|c|c|c|c|c|}
\hline \multirow[t]{2}{*}{ Age (y) } & \multirow[t]{2}{*}{ Sex } & \multicolumn{2}{|c|}{ Age (y) } & \multicolumn{2}{|c|}{ Height (m) } & \multicolumn{2}{|c|}{ Weight (kg) } & \multicolumn{2}{|c|}{$\begin{array}{l}\text { Weight/height }{ }^{2} \\
\left(k^{-2}\right)\end{array}$} & \multicolumn{2}{|c|}{$\begin{array}{l}\text { FFM/height }{ }^{2} \\
\left(k^{-2}\right)\end{array}$} & \multicolumn{2}{|l|}{$\%$ fat } \\
\hline & & Mean & $(S D)$ & Mean & $(S D)$ & Mean & $(S D)$ & Mean & $(S D)$ & Mean & $(S D)$ & Mean & $(S D)$ \\
\hline $38-47$ & $\begin{array}{l}\text { Male } \\
\text { Female } \\
\text { Male } \\
\text { Female } \\
\text { Male } \\
\text { Female }\end{array}$ & $\begin{array}{l}21.56 \\
21.19 \\
31.25 \\
32.06 \\
42.57 \\
41.30\end{array}$ & $\begin{array}{l}(2.50) \\
(2.80) \\
(2.80) \\
(2.44) \\
(3.76) \\
(1.97)\end{array}$ & $\begin{array}{l}1.69 \\
1.57 \\
1.69 \\
1.54 \\
1.70 \\
1.59\end{array}$ & $\begin{array}{l}(6.10) \\
(5.62) \\
(6.67) \\
(4.38) \\
(3.92) \\
(3.59)\end{array}$ & $\begin{array}{l}56.94 \\
52.21 \\
62.43 \\
53.66 \\
69.61 \\
58.93\end{array}$ & $\begin{array}{l}(7.18) \\
(7.02) \\
(8.05) \\
(6.20) \\
(6.62) \\
(7.23)\end{array}$ & $\begin{array}{l}19.79 \\
21.18 \\
21.72 \\
22.78 \\
24.85 \\
22.81\end{array}$ & $\begin{array}{l}(2.08) \\
(3.31) \\
(2.47) \\
(3.39) \\
(2.56) \\
(3.44)\end{array}$ & $\begin{array}{l}17.53 \\
15.49 \\
18.71 \\
16.39 \\
20.13 \\
16.21\end{array}$ & $\begin{array}{l}(1.48) \\
(1.41) \\
(2.17) \\
(1.57) \\
(1.62) \\
(1.31)\end{array}$ & $\begin{array}{l}11.28 \\
26.96 \\
14.35 \\
27.78 \\
18.76 \\
27.47\end{array}$ & $\begin{array}{l}(3.49) \\
(5.89) \\
(4.97) \\
(6.29) \\
(3.88) \\
(7.37)\end{array}$ \\
\hline
\end{tabular}

Table 3 Means and standard deviations (SD) of the lung function indices in the subjects

\begin{tabular}{|c|c|c|c|c|c|c|c|c|c|c|c|}
\hline \multirow[t]{2}{*}{ Age (y) } & \multirow[t]{2}{*}{ Sex } & \multicolumn{2}{|c|}{$F V C(l)$} & \multicolumn{2}{|c|}{$F E V_{1}(l)$} & \multicolumn{2}{|c|}{$F E V, \%$} & \multicolumn{2}{|c|}{$F E F\left(l s^{-1}\right)$} & \multicolumn{2}{|c|}{$\operatorname{PEFR}\left(l s^{-1}\right)$} \\
\hline & & Mean & $(S D)$ & Mean & $(S D)$ & Mean & $(S D)$ & Mean & $(S D)$ & Mean & $(S D)$ \\
\hline $\begin{array}{l}18-27 \\
28-37\end{array}$ & $\begin{array}{l}\text { Male } \\
\text { Female } \\
\text { Male } \\
\text { Female } \\
\text { Male } \\
\text { Female }\end{array}$ & $\begin{array}{l}4.60 \\
3.16 \\
4.57 \\
3.04 \\
4.10 \\
2.82\end{array}$ & $\begin{array}{l}(0.67) \\
(0.42) \\
(0.82) \\
(0.53) \\
(0.54) \\
(0.51)\end{array}$ & $\begin{array}{l}4.09 \\
2.65 \\
3.79 \\
2.49 \\
3.35 \\
2.29\end{array}$ & $\begin{array}{l}(0.55) \\
(0.39) \\
(0.76) \\
(0.39) \\
(0.49) \\
(0.42)\end{array}$ & $\begin{array}{l}89.04 \\
83.89 \\
82.79 \\
81.76 \\
81.95 \\
80.91\end{array}$ & $\begin{array}{l}(5.66) \\
(7.76) \\
(5.04) \\
(7.18) \\
(5.49) \\
(5.26)\end{array}$ & $\begin{array}{l}7.16 \\
3.98 \\
6.71 \\
4.21 \\
6.30 \\
3.54\end{array}$ & $\begin{array}{l}(1.95) \\
(1.24) \\
(2.14) \\
(1.61) \\
(1.08) \\
(1.29)\end{array}$ & $\begin{array}{l}9.33 \\
6.76 \\
8.87 \\
6.50 \\
8.49 \\
5.42\end{array}$ & $\begin{array}{l}(1.67) \\
(0.90) \\
(1.31) \\
(0.94) \\
(1.08) \\
(0.81)\end{array}$ \\
\hline
\end{tabular}

caliper at the triceps, biceps, and subscapular and suprailiac regions, where good folds of skin can be raised. The measurements of FVC, $\mathrm{FEV}_{1}, \mathrm{FEV}_{1} \%$, and FEF were derived from a single forced expiratory spirogram recorded by a Vitalograph spirometer. PEFR was measured by the mini Wright peak flow meter. Subjects were instructed to practise the manoeuvre before being attached to the instrument. Noseclips were used; the test was performed in a standing position. After the practice blow the recording was done three times and the best of the three readings was taken. All volumes were recorded at ambient temperatures of $20-24^{\circ} \mathrm{C}$ and corrected to body temperature and pressure saturated with water vapour (BTPS) by reference to the right hand scale on the standard Vitalograph chart, which increases volumes assumed to have been recorded at a temperature of $20^{\circ} \mathrm{C}$ by a factor of 1.1. The spirometer was calibrated at the beginning of the investigation.

Results were analysed with the NCR 8500 Multiple Regression program. The lung function indices for males and females were related to: $(a)$ age and height; (b) age, height, and weight/height ${ }^{2} ;(c)$ age, height, percentage fat, and FFM/height ${ }^{2}$. An attempt was made to formulate regression equations. Student's $t$ test was used for statistical analysis, the $5 \%$ probability level being taken as significant.

\section{Results}

The means and standard deviations of the anthropometric measurements and of the lung function indices of the men and women by age groups are given in tables 2 and 3 . Table 4 shows that weight/height ${ }^{2}$ regressed significantly with FVC and PEFR in the men and with only PEFR in the women. The regression relationship of FVC, FEV and FEF in men is better defined when the additional terms percentage body fat and FEM/height ${ }^{2}$ are considered with age and height (table 4). In the women, however, the results show that the contribution of percentage body fat and FFM/height ${ }^{2}$ as determinants of lung function appears to be neglig-

Table 4 Contributions of age, height, weight/height ${ }^{2}\left(W t / H t^{2}\right)$, percentage fat, and fat free mass (FFM)/height ${ }^{2}$ to the description of lung function in men and women

\begin{tabular}{|c|c|c|c|c|c|c|c|c|c|c|}
\hline & \multicolumn{5}{|l|}{ Men } & \multicolumn{5}{|c|}{ Women } \\
\hline & Age & Height & $W t / H t^{2}$ & $\%$ fat & $F F M / H t^{2}$ & Age & Height & $W t / H t^{2}$ & $\%$ fat & $F F M / H t^{2}$ \\
\hline $\begin{array}{l}\text { FVC } \\
\text { FEV } \\
\text { FEV'\% } \\
\text { FEF } \\
\text { PEFR }\end{array}$ & $\begin{array}{l}- \\
- \\
\text { NS } \\
-\end{array}$ & $\begin{array}{l}+ \\
+ \\
(-) \\
\text { NS } \\
+\end{array}$ & $\begin{array}{l}+ \\
\text { NS } \\
\text { NS } \\
\text { NS } \\
(+)\end{array}$ & $\begin{array}{l}(-) \\
\text { NS } \\
- \\
\text { NS }\end{array}$ & $\begin{array}{l}(+) \\
(+) \\
\text { NS } \\
+ \\
+\end{array}$ & $\begin{array}{l}- \\
- \\
- \\
\text { NS } \\
-\end{array}$ & $\begin{array}{l}+ \\
+ \\
\text { NS } \\
\text { NS } \\
\text { NS }\end{array}$ & $\begin{array}{l}\text { NS } \\
\text { NS } \\
\text { NS } \\
\text { NS } \\
(+)\end{array}$ & $\begin{array}{l}\text { NS } \\
\text { NS } \\
\text { NS } \\
\text { NS } \\
\text { NS }\end{array}$ & $\begin{array}{l}\text { NS } \\
\text { NS } \\
\text { NS } \\
\text { NS } \\
+\end{array}$ \\
\hline
\end{tabular}

FVC - forced vital capacity; FEF - forced expiratory flow; PEFR - peak expiratory flow rate; NS - not significant; + and - indicate a significant regression coefficient of the lung function index on the variable in question. Where more than one term is significant, the one that gives the least good fit is indicated by parentheses. 
Table 5 Comparisons of predicted values of FVC and FEV for age and height in different ethnic groups (a standard man: age 40 years, height $170 \mathrm{~cm}$; a standard woman: age 40 years, height $160 \mathrm{~cm}$ )

\begin{tabular}{|c|c|c|c|c|}
\hline Ethnic group & Reference & Index & Male & Female \\
\hline $\begin{array}{l}\text { Swedish } \\
\text { European } \\
\text { American (Caucasian) } \\
\text { Bantu } \\
\text { Chinese } \\
\text { Zimbabwe } \\
\text { Sudanese } \\
\text { Indian } \\
\text { Ethiopian }\end{array}$ & $\begin{array}{l}\text { Berglund et } a l^{2} \\
\text { Cotes } e t a l^{3} \\
\text { Morris } e t a l^{15} \\
\text { Johannesen and Erasmus } \\
\text { Da Costa } \\
\text { Cookson } e t a l^{10} \\
\text { Mustafa } \\
\text { Miller } e t a l^{7} \\
\text { Present Study }\end{array}$ & $\begin{array}{l}\text { FVC } \\
\text { FEV, } \\
\text { FVC } \\
\text { FEV, } \\
\text { FVC } \\
\text { FEV, } \\
\text { FVC' } \\
\text { FEV, } \\
\text { FVC' } \\
\text { FEV, } \\
\text { FVC } \\
\text { FEV, } \\
\text { FVC } \\
\text { FEV, } \\
\text { FVC } \\
\text { FEV, } \\
\text { FVC } \\
\text { FEV, }\end{array}$ & $\begin{array}{l}4.96 \\
3.88 \\
4.37 \\
3.51 \\
4.62 \\
3.58 \\
3.98 \\
2.85 \\
3.77 \\
2.71 \\
3.63 \\
3.13 \\
3.49 \\
3.08 \\
3.45 \\
2.84 \\
4.35 \\
3.52\end{array}$ & $\begin{array}{l}3.14 \\
2.94 \\
- \\
3.89 \\
2.67 \\
2.70 \\
2.22 \\
2.61 \\
2.25 \\
2.77 \\
2.37 \\
- \\
- \\
2.67 \\
2.11 \\
3.11 \\
2.45\end{array}$ \\
\hline
\end{tabular}

ible, although PEFR shows significant regression coefficients with weight and fat free mass expressed independenly of height.

The regressions of FVC, FEV , and PEFR against age and height are best expressed in both sexes by the following equations (in which $\mathrm{A}=$ age in years and $\mathrm{H}=$ height in metres):

\begin{tabular}{|c|c|c|c|c|}
\hline \multirow{3}{*}{$\begin{array}{l}\text { Index } \\
\text { FVC }\end{array}$} & Sex & Prediction formula & & $S E E$ \\
\hline & $\mathbf{M}$ & $\begin{array}{l}-6.6839-0.0195 \mathrm{~A}+ \\
0.0695 \mathrm{H}\end{array}$ & 0.63 & 0.58 \\
\hline & $\mathbf{F}$ & $\begin{array}{l}-2.9208-0.0122 \mathrm{~A}+ \\
0.0407 \mathrm{H}\end{array}$ & 0.47 & 0.47 \\
\hline FEV $_{1}$ & $\mathbf{M}$ & $\begin{array}{l}-3.6679-0.0331 \mathrm{~A}+ \\
0.0501 \mathrm{H}\end{array}$ & 0.64 & 0.50 \\
\hline & $\mathbf{F}$ & $\begin{array}{l}-1.6158-0.0178 \mathrm{~A}+ \\
0.0298 \mathrm{H}\end{array}$ & 0.44 & 0.47 \\
\hline PEFR & $\mathbf{M}$ & $\begin{array}{l}-0.1545-0.0532 \mathrm{~A}+ \\
0.0625 \mathrm{H}\end{array}$ & 0.43 & 1.20 \\
\hline & $\mathbf{F}$ & $-7.7849-0.0461 \mathrm{~A}$ & 0.38 & 1.05 \\
\hline
\end{tabular}

Since the altitude of the subjects' residence showed no significant relation to lung function values in given age and sex groups readings were grouped only by age and sex.

\section{Discussion}

The results suggest that the lung function indices, in particular FVC and $\mathrm{FEV}_{1}$, increase with increasing stature in both sexes which is in agreement with previous findings. ${ }^{1-46-812-1516}$ The sex difference in all the indices is apparent, although for $\mathrm{FEV}_{1} \%$ the mean values (table 3 ) for women are unexpectedly low compared with those of the men. This may be due to poor cooperation or poor muscular effort of the women studied. In the women FVC and FEV, showed a significant regression only against age and height; advancing age is a good indicator of the decrease in FEV $\%$ and PEFR in both sexes. The results indicate that in the men percentage fat and fat free mass expressed independently of height can be considered in predicting FVC, FEV , and PEFR.

The functional efficiency of the lung deteriorates with age. ${ }^{7}$ This is also shown in table 3 . Besides genetic factors, altitude and customary physical activity may be some of the factors that determine lung function variations. The Ethiopian populations we studied, residing at altitudes of $1585-2757 \mathrm{~m}$, were not engaged in any form of unusual physical activity and were essentially sedentary subjects. When comparison is made using a standard age and

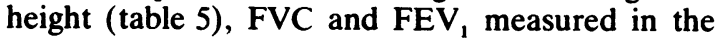
Ethiopians are found to be lower than in whites, ${ }^{2} 315$ but higher than in other Africans, ${ }^{6111216}$ Chinese, ${ }^{8}$ and Indians. ${ }^{7}$ The differences observed in these indices among the ethnic groups may be attributable to genetic factors, physical make up inherent in the ethnic groups, altitude, environmental differences, physical activities, and tobacco smoking.

We are aware of the altered performance of the Vitalograph spirometer under extremes of temperature..$^{19} \mathrm{~A}$ small error is introduced if correction to BTPS is made from temperatures well above $20^{\circ} \mathrm{C}$ and a large error if correction is made for recordings made at low temperatures. Our recordings were made under temperate conditions and we do not think that significant systematic error can have been introduced by this means.

The respiratory study made in the Ethiopian populations by Harrison and associates ${ }^{20}$ comprised subjects with relatively greater mean ages than the subjects of the present study. Information on smoking habits of the individuals is lacking and most of the subjects were neither healthy nor permanent 
residents at a given altitude. For these reasons comparison is not warranted, and the lung function indices obtained cannot be considered as standard values. We believe that the results of the present study offer a useful basis for predicting mean normal values for lung function indices in adult Ethiopians.

We are very grateful to Wubit Assefa and Drs DM Minter and RB Douglas for their help in preparing this paper, which is part of an MSc dissertation presented to the School of Graduate Studies, Addis Ababa University, in July 1980. The work was supported in part by a grant from the Swedish Agency for Research Cooperation with Developing Countries (SAREC).

\section{References}

1 Kory RC, Callahan R, Boren HG, Synder JC. The Veterans Administration-Army Cooperative study of pulmonary function. I. Clinical spirometry in normal men. Am J Med 1961;30:243-58.

2 Berglund E, Birath G, Bjure J, et al. Spirometric studies in normal subjects. I. Forced expirograms in subjects between 7 and 70 years of age. Acta Med Scand 1963;173:185-91.

3 Cotes JE, Russiter CE, Higgins ITT, Gilson JC. Average normal values for the forced expiratory volume in white caucasian males. $\mathrm{Br} \mathrm{Med} J$ 1966; i:1016-9.

4 Ringqvist $T$. The ventilatory capacity in healthy subjects. Scand J Clin Lab Invest 1966:18, suppl: 88, 128-36.

5 Cotes JE, Malhorta MS. Differences in lung function between Indians and Europeans. $J$ Physiol 1965; 177:17P (abstract).

6 Johannesen ZM, Erasmus LD. Spirometry in normal Bantu. Am Rev Respir Dis 1968;97:585-97.
7 Miller GJ, Ashcroft MT, Swan AV, Beadnell HMSG. Ethnic variation in FEV, and FVC of African and Indian adults in Guyana. Am Rev Respir Dis 1970; 102:979-81.

$8 \mathrm{Da}$ Costa JL. Pulmonary function studies in healthy Chinese adults in Singapore. Am Rev Respir Dis 1971;104:128-31.

9 Miller GJ, Cotes JE, Hall AM, Salvosa CB, Ashworth A. Lung function and exercise performance of healthy Caribbean men and women of African ethnic origin. $Q$ J Exp Physiol 1972;57:325-41.

10 Oscherwitz M, Edlavitch SA, Baker TR, Jarboe T. Differences in pulmonary functions in various racial groups. Am J Epidemiol 1972;96:319-27.

11 Femi-Pearse D, Elebute EA. Ventilatory function in healthy adult Nigerians. Clin Sci 1971;41:203-11.

12 Mustafa KY. Spirometric lung function tests in normal men of African ethnic origin. Am Rev Respir Dis 1977; 116:209-13.

13 British Medical Research Council. The aetiology of chronic bronchitis. Lancet 1965;i:775.

14 Durnin JVGA, Rahaman MM. The assessment of the amount of fat in the human body from measurement of skinfold thickness. Br J Nutrition 1967;21:681-9.

15 Morris JF, Koski A, Johnson LC. Spirometric standards for healthy non-smoking adults. Am Rev Respir Dis 1971;103:57-67.

16 Cookson JB, Blake GTW, Faranisic C. Normal values for ventilatory function in Rhodesian Africans. $\mathrm{Br} J$ Dis Chest 1976;70:107-11.

17 Cotes JE. Lung function: assessment and application in medicine. 2nd ed. Oxford: .Blackwell Scientific Publications, 1968:296-303.

18 Perks WH, Sopwith T, Brown D, Jones $\mathrm{CH}$, Green M. Effects of temperature on Vitalograph spirometer readings. Thorax 1983;38:592-4.

19 Cramer D, Peacock A, Denison D. Temperature corrections in routine spirometry. Thorax 1984;39:771-4.

20 Harrison GA, Kuchemann CF, Moore MAS, et al. The effects of altitudinal variation in Ethiopian populations. Phil Trans R Soc London 1969;256:147-82. 